Marquette University

e-Publications@Marquette

$10-1-2015$

Resourcefulness in African American and Caucasian American Caregivers of Persons With Dementia: Associations With Perceived Burden, Depression, Anxiety, Positive Cognitions, and Psychological Well-Being

Abir K. Bekhet

Marquette University, abir.bekhet@marquette.edu

Accepted version. Perspectives in Psychiatric Care, Vol. 51, No. 4 (October 2015): 285-294. DOI. (C) 2014 Wiley Periodicals, Inc. Used with permission.

This is the peer reviewed version of the following article: "Resourcefulness in African American and Caucasian American Caregivers of Persons With Dementia: Associations With Perceived Burden, Depression, Anxiety, Positive Cognitions, and Psychological Well-Being," Perspectives in Psychiatric Care, Vol. 51, No. 4 (October 2015): 285-294, which has been published in final form at DOI. This article may be used for non-commercial purposes in accordance With Wiley Terms and Conditions for self-archiving'. 


\title{
Resourcefulness in African American and Caucasian American Caregivers of Persons with Dementia: Associations with Perceived Burden, Depression, Anxiety, Positive Cognitions, and Psychological Well- Being
}

\author{
Abir K. Bekhet \\ College of Nursing, Marquette University \\ Milwaukee, WI
}

\begin{abstract}
Purpose: Providing care to persons with dementia can have negative effects on caregivers' physical and psychological well-being. This secondary analysis explored relationships among perceived burden, depression, anxiety, resourcefulness, and psychological well-being in 28 African American (AA) and 45 Caucasian American (CA) caregivers of persons with dementia.

Design and Methods: Descriptive, cross-sectional design was used to examine the hypothesized relationships in a sample of 73 caregivers.

Findings: CAs reported greater burden $(t=-3.68, p<.001)$, more anxiety $(t=-2.66, p<.01)$, depression $(t=-2.21, p<.05)$, and hostility $(t=$


$-2.30, p<.05)$ than AAs. AAs reported higher scores than CAs on resourcefulness, positive cognitions, and psychological well-being.

Practice Implications: The study findings provided directions for the development of resourcefulness interventions to enhance the psychological well-being among dementia caregivers.

The population of older adults is increasing rapidly: by 2030, adults aged 65 and older are expected to make up $20 \%$ of the American population with a census of 71 million (Centers for Disease Control and Prevention, 2011). As a result, the number of persons affected with Alzheimer's disease will increase as well. Alzheimer's disease and related dementias affect approximately 5.4 million persons in the United States, a number that is expected to triple to 11-16 million by 2050 (Alzheimer's Association, 2012). Dementia is characterized by declines in memory and cognitive abilities that affect the person's coherent speech, abstract thinking, object identification, motor activities, and social abilities, and eventually interfere with the individual's ability to carry out daily activities, necessitating the need for caregiving (Huang, Chang, Tang, Chiu, \& Weng, 2008; Plassman et al., 2007; Tremont, 2011).

In the United States, it has been estimated that 15 million persons provide 17.4 billion hours of unpaid care and an estimated $80 \%$ of the care is provided at home by family members (Alzheimer's Association, 2012). For family members of persons with dementia, caregiving can involve considerable burden (Alwin, Oberg, \& Krevers, 2010; Etters, Goodall, \& Harrison, 2008; Kim, Chang, Rose, \& Kim, 2012; Pinquart \& Sörensen, 2004; Schoenmakers, Bntinx, \& Delepeleire, 2010). Caregiver burden has been defined as "a multidimensional response to the negative appraisal and perceived stress resulting from taking care of an ill person" (Kim et al., 2012, p. 846). High levels of depressive symptoms have been documented among caregivers of persons with dementia (CPD) and one third of these caregivers meet the diagnostic criteria for clinical depression (Cooper, Katona, Orrell, \& Livingston, 2008; Fisher et al., 2011; Flynn Longmire \& Knight, 2010; Schultz \& Martire, 2004; Tremont, 2011). In addition, high levels of anxiety have been found in 10-35\% of CPD (Cooper, Katona, Orrell, \& Livingston, 2006; Cooper, Balamurali, \& Livingston, 2007; Cooper, Balamurali, Selwood, \& Livingston, 2007; Cooper et al., 2008). Cooper et al. (2008) pointed out that anxiety disorder and its symptoms are frequently associated with depression

Perspectives in Psychiatric Care, Vol 51, No. 4 (October 2015): pg. 285-294. DOI. This article is (C Wiley and permission has been granted for this version to appear in e-Publications@Marquette. Wiley does not grant permission for this article to be further copied/distributed or hosted elsewhere without the express permission from. 
and may be the most common among CPD; however, treatment of anxiety disorders and its symptoms has been neglected to some extent (Cooper et al., 2008). In sum, previous research has shown that providing care and support to persons with dementia can have adverse effects on caregivers' physical health, mental health, and psychological well-being (Di Mattei etal., 2008; Oken, Fonareva, \& Wahbeh, 2011; Romero-Moreno et al., 2011; Schoenmakers et al., 2010; Van Vliet, de Vugt, Bakker, Koopmans, \& Verhey, 2010).

However, researchers have also noted that positive experiences are associated with caregiving as described by the family members of persons with dementia. These positive experiences include finding meaning and joy in providing care; as a result, caregivers experience positive mental health and reduced levels of stress (Butcher, Holkup, \& Buckwalter, 2001; Depp etal., 2005; Duggleby, Williams, Wright, \& Bollinger, 2009). Clearly, these people were able to adapt, cope, and rise above their challenges.

\section{Theoretical Framework}

Learning to adapt to challenging life experiences includes acquiring specific self-control skills that constitute "resourcefulness" and help a person to manage potentially adverse situations (Rosenbaum, 1990). Two types of resourcefulness have been identified: personal (self-help) and social (help seeking) resourcefulness (Zauszniewski, 2006). Previous research has shown that resourcefulness is associated with positive affect, fewer depressive cognitions, and better psychological and physical health (Zauszniewski, Bekhet, Lai, McDonald, \& Musil, 2007; Zauszniewski, Chung, \& Krafcik, 2001).

Zauszniewski's middle range theory of resourcefulness provides the theoretical framework for this study. The resourcefulness theory has four major constructs: contextual factors, process regulators, resourcefulness skills, and quality of life (QOL) (Zauszniewski, 2006). This theory proposed that there are two types of contextual factors which are intrinsic and extrinsic. Intrinsic factors are intrapersonal while extrinsic factors are extrapersonal (Zauszniewski, 2006). In this study, race is conceptualized as a contextual intrinsic factor that could affect the resourcefulness and QOL among CPD. Process regulators are

Perspectives in Psychiatric Care, Vol 51, No. 4 (October 2015): pg. 285-294. DOI. This article is (C Wiley and permission has been granted for this version to appear in e-Publications@Marquette. Wiley does not grant permission for this article to be further copied/distributed or hosted elsewhere without the express permission from. 
variables that could intervene to attenuate the effects of the contextual factors on personal and social resourcefulness. Positive cognitions are conceptualized as process regulators in this study. Positive cognitions refer to specific positive thinking patterns that increase the caregivers' abilities to manage their daily activities and to promote their mental health (Zauszniewski, McDonald, Krafcik, \& Chung, 2002). The outcome in the model is QOL, which is conceptualized as psychological well-being in this study and was conceptualized as psychological well-being in previous research conducted by Dr. Zauszniewski, the developer of the middle range theory of resourcefulness (Zauszniewski, 2006).

Research on resourcefulness is lacking among CPD. Only two studies have examined resourcefulness in dementia caregivers. The first study was done in Hong Kong and involved teaching cognitive behavioral strategies to CPD (Au et al., 2010). The authors concluded that their intervention improved the resourcefulness of CPD. However, no scale was used to measure resourcefulness in their study; rather, they measured resourcefulness by the caregiving self-efficacy scale that contains three subscales: obtaining respite, responding to disruptive patient behaviors, and controlling upsetting thoughts ( $\mathrm{Au}$ et al., 2010). The second study by Gonzalez (1997) examined similarities and differences in appraisals of behavioral problems, resourcefulness, and coping resources between African Americans (AAs) and Anglo Americans. However, in their study, resourcefulness was measured only by the self-control schedule (Rosenbaum, 1990). Researchers have found that this measure captures the individual's personal resourcefulness but does not assess the help-seeking skills that comprise social resourcefulness. Yet, both personal and social resourcefulness are important in predicting health outcomes (Zauszniewski, Lai, \& Tithiphontumrong, 2006). Further, research has shown that individuals who have both personal and social resourcefulness report less anxiety, depression, and better health outcomes than those who are high either only in social or personal resourcefulness (Bekhet, Zauszniewski, \& Wykle, 2008; Zauszniewski et al., 2006).

Studies have shown that AA caregivers are susceptible to more health problems and report poorer health than Caucasian American (CA) caregivers, possibly because of the multiple stressors they 
encounter, such as poverty, unemployment, and racism (Belgrave, Wykle, \& Choi, 1993; Gonzalez, 1997; Tremont, 2011; Young \& Kahana, 1995). Yet, research has also found that AA caregivers showed more resilience, less burden, less psychological stress, and lower levels of depression in the face of the challenging situations associated with caregiving than CA caregivers (Belgrave et al., 1993; Clay, Roth, Wadley, \& Haley, 2008; Haley et al., 1996; Hinrichsen \& Ramirez, 1992; Lawton, Rajagopal, Brody, \& Kleban, 1992; Sörensen \& Pinquart, 2005; Sleath, Thorpe, Landerman, Doyle, \& Clipp, 2005).

Therefore, this study examined both forms of resourcefulness in relation to burden, anxiety, depression, and psychological well-being of AA and CA CPD as suggested by Zauszniewski's theory of resourcefulness and QOL (Zauszniewski, 2006).

The aims of the present study are (a) to examine the differences between AA and CA CPD in terms of burden, symptoms (depression, anxiety, somatic symptoms, and anger hostility), psychological wellbeing, positive cognitions, and personal and social resourcefulness and (b) to examine the correlations between positive cognitions, personal and social resourcefulness, psychological well-being, perceived burden, and the symptoms subscale of the Symptom Questionnaire (SQ).

\section{Methods}

The study was a secondary analysis of data from a crosssectional study of 80 CPD. The original study used a descriptive and cross-sectional design to assess the mediating effects of positive cognitions on the relationship between caregivers' burden and resourcefulness in 80 CPD (Bekhet, 2013). In the parent study, the Institutional Review Board approval was obtained and subjects were recruited by administrators at the Alzheimer's Association early stage programs in Southeastern Wisconsin Chapter of the Alzheimer's Association (SEWAA), which serves an 11-county region that includes Milwaukee County. The chapter provides numerous educational and supportive programs for persons living with dementia, their care partners, and family members. The SEWAA shared information about the research project with caregivers that their interface with via their programs and services. Furthermore, they provided caregivers a onepage flyer about the project.

Perspectives in Psychiatric Care, Vol 51, No. 4 (October 2015): pg. 285-294. DOI. This article is (C Wiley and permission has been granted for this version to appear in e-Publications@Marquette. Wiley does not grant permission for this article to be further copied/distributed or hosted elsewhere without the express permission from. 
Those caregivers who were interested contacted the researchers and completed a consent form and the study questionnaire. On an agreed-upon date and time, the research assistant distributed the questionnaires to caregivers and collected them on the spot after 45$60 \mathrm{~min}$, so there was no dropping. The subjects either agreed or declined to participate in the study. The research assistant doublechecked the completion of each questionnaire in order to minimize the missing data (Bekhet, 2013).

In the original study, caregivers were given a $\$ 15$ gift card to thank them for their time and participation. The study compared 45 White CAs and 28 AAs on measures of burden, depression, anxiety, resourcefulness, and psychological well-being in the light of Zauszniewski's theory of resourcefulness (Zauszniewski, 2006). Seven participants in the original study were excluded from the analysis because they represented other races/ethnicities (Hispanic, Asian, or others).

The sample size was evaluated for this analysis that required the use of $t$ tests and correlational analyses. As this was the first study to examine the burden, depression, resourcefulness, and psychological well-being in AA and CA CPD, a large effect size was used to estimate power (Cohen, 1992). With sample sizes of 28 and 45 caregivers in each of the two groups of caregivers, there is sufficient power (91\%) to detect a large effect size of $d=0.8$ with a $5 \%$ level of significance in a two-tailed $t$ test.

According to Munro (1997), the effect size should be based on previous works. It should be noted that no study has explored the relationship among these study variables in relation to CA and AA CPD. However, previous research conducted by Zauszniewski (1994) aimed at examining the relationship among resourcefulness, depressive symptoms, and adaptive functioning in depressed and nondepressed adults. Results indicated that learned resourcefulness was the only significant predictor of depression accounting for $39 \%$ of the variance. According to Cohen and Cohen (1983), a variance of .25 corresponds to large effect size.

Perspectives in Psychiatric Care, Vol 51, No. 4 (October 2015): pg. 285-294. DOI. This article is (C Wiley and permission has been granted for this version to appear in e-Publications@Marquette. Wiley does not grant permission for this article to be further copied/distributed or hosted elsewhere without the express permission from. 


\section{Plan for Data Analysis and Management}

Prevention of missing data is the best approach to deal with the problem of missing data (Stone, 2001). However, for this study, missing data were minimal because data were collected by distribution of the questionnaire to CPD on an agreed-upon date and time. The research assistant double-checked the questionnaires after collecting the data to make sure that all items had been answered (Bekhet, 2013).

Descriptive statistics, including means, standard deviations, and ranges, were used to describe the sample. The independent $t$ test was used to compare the AA and the CA CPD in regard to the major study variables. Pearson's correlation analysis was used to examine the associations among psychological well-being, burden, and caregivers' symptom subscale and the main study variables, including positive cognitions and personal and social resourcefulness. We examined correlations for the total sample and then separately for AAs and CAs.

\section{Instruments}

\section{Caregiver Burden}

Caregiver burden was assessed by the 22-item Zarit Burden Interview (ZBI), which is the most widely used measure of burden among family of CPD (Knight, Silverstein, McCallum, \& Fox, 2000). The ZBI uses a 5-point Likert scale that ranges from 0 (never) to 4 (nearly always); scores range from 0 to 88 with higher scores indicating greater burden. The ZBI is a reliable measure, as indicated by Cronbach's alphas that range from .88 to .92 (Chou, Chu, Tseng, \& Lu, 2003; Thompson, Futterman, Gallagher-Thompson, Rose, \& Lovett, 1993). Cronbach's alpha for ZBI in this study was .93.

\section{Positive Cognitions}

The 8-item Depressive Cognition Scale (DCS) was used to measure positive cognitions in this study (Zauszniewski, 1995). All the items of the DCS are phrased in a positive direction so the scale measures positive cognitions when scores are not reversed

Perspectives in Psychiatric Care, Vol 51, No. 4 (October 2015): pg. 285-294. DOI. This article is (C Wiley and permission has been granted for this version to appear in e-Publications@Marquette. Wiley does not grant permission for this article to be further copied/distributed or hosted elsewhere without the express permission from. 
(Zauszniewski, Chung, Krafcik, \& Sousa, 2001). The DCS uses a 6point Likert scale that describes the caregivers' current thoughts from 5 (strongly agree) to 0 (strongly disagree) (Zauszniewski, 1995; Zauszniewski, Chung, Krafcik, \& Sousa, 2001). Scores can range from 0 to 40; higher scores indicate a greater number of positive cognitions when scores are not reversed (Zauszniewski, 1997). The DCS has demonstrated reliability and validity as indicated by Cronbach's alpha of .78 and significant correlations in the expected directions $(p<.001)$ with measures of depression, resourcefulness, adaptive functioning, and life satisfaction ( $r \mathrm{~s}=.54,-.37,-.60$, and -.57 , respectively) (Zauszniewski, 1995). Cronbach's alpha for the DCS in this study was .88.

Resourcefulness was assessed by the 28-item self-report Resourcefulness Scale (RS) (Zauszniewski et al., 2006). The RS consists of two subscales; 16 items measure personal resourcefulness or the individual's tendencies to apply self-help, and 12 items measures social resourcefulness or help-seeking behaviors (Zauszniewski et al., 2006). The RS uses a 6-point scoring system ranging from 0 (not at all like me) to 5 (very much like me) (Zauszniewski et al., 2006). Scores may range from 0 to 140, with higher scores indicating greater personal and social resourcefulness (Zauszniewski et al., 2006). The RS has acceptable internal consistencies with Cronbach's alphas of .83, .79, and .85 for the total scale and personal and social resourcefulness subscales, respectively (Zauszniewski et al., 2006). Confirmatory factor analysis indicated construct validity by the emergence of two dimensions of resourcefulness (personal and social) with strong correlations between the two $(r=.41, p<.001)$ (Zauszniewski et al., 2006). Cronbach's alpha for RS in this study was .92. Alphas for the social resourcefulness subscale and the personal subscale in this study were .84 and .89 , respectively.

The SQ was used to measure symptoms and psychological wellbeing (Kellner, 1987). The SQ is a 92-item yes/no questionnaire with brief, simple items. It consists of four symptom subscales, namely depression, anxiety, somatic symptoms, and anger hostility, and each symptom subscale has a corresponding well-being subscale. The SQ includes items that indicate symptoms and items that indicate wellbeing. Respondents score 1 for each symptom on which they check

Perspectives in Psychiatric Care, Vol 51, No. 4 (October 2015): pg. 285-294. DOI. This article is (C Wiley and permission has been granted for this version to appear in e-Publications@Marquette. Wiley does not grant permission for this article to be further copied/distributed or hosted elsewhere without the express permission from. 
YES, and score 1 for each statement of well-being on which they check NO. Reliabilities reported for the anxiety, depression, somatic symptoms, and hostility subscales were .92, .94, .86, and .91, respectively. The well-being subscale includes 24 items that measure psychological well-being. On the two subscales (subscales of symptoms and well-being), higher scores indicate less stress or more well-being. The SQ was validated in a study of elderly subjects in which total SQ scores significantly increased after crises and were positively correlated with serum cortisol level and negatively correlated with caloric intake (Willis, Thomas, Garry, \& Goodwin, 1987). Cronbach's alpha for the psychological well-being subscale in this study was .76 and Cronbach's alphas for the hostility, somatic symptoms, depression, and anxiety subscales in this study were $.88, .85, .89$, and .86 , respectively.

\section{Results}

The average age of all caregivers was 57.46 years. For AAs, the mean age of caregivers was 47.39 years while the mean age of $C A$ caregivers was 64.16 years. All AA caregivers were females $(n=28)$ and the majority of CA caregivers $(84.4 \%$ ) were also females ( $n=$ 38). Almost half of the AA caregivers had some college or associate degree representing $46.4 \%(n=13)$. On the other hand, more than half of the CA caregivers (51.1\%) had college or graduate education. For AA caregivers, $21.5 \%$ had some high school or high school education, and $32.2 \%$ had college or graduate education. For CA caregivers, $22.2 \%$ had some college/associate degree and $26.7 \%$ had some high school or high school education. More than half of the CA caregivers (51.1\%) reported having an income of $\$ 45,000$ or more, while $14.3 \%$ of the AA caregivers reported having an income of $\$ 45,000$ or more. Regarding the caregivers' health, $35.5 \%$ and $10.7 \%$ of CA and AA caregivers, respectively, rated their health as excellent. Regarding the persons with dementia, the mean age for AAs was 79.96 years while the mean age for CAs was 83.47 years. About $71.5 \%$ of AA persons with dementia were females as compared to $62.2 \%$ of CA persons with dementia (Table 1 ).

Perspectives in Psychiatric Care, Vol 51, No. 4 (October 2015): pg. 285-294. DOI. This article is (C Wiley and permission has been granted for this version to appear in e-Publications@Marquette. Wiley does not grant permission for this article to be further copied/distributed or hosted elsewhere without the express permission from. 
NOT THE PUBLISHED VERSION; this is the author's final, peer-reviewed manuscript. The published version may be accessed by following the link in the citation at the bottom of the page.

Table 1. Characteristics of the Sample

\begin{tabular}{lll}
$\begin{array}{l}\text { Variable (caregivers characteristics) } \\
\text { Age }\end{array}$ & \multicolumn{1}{c}{$\begin{array}{c}\text { African American (AA) } \\
n=28(\%)\end{array}$} & \multicolumn{1}{c}{$\begin{array}{c}\text { Caucasian American (CA) } \\
n=45(\%)\end{array}$} \\
$\begin{array}{l}\text { Mean }(S D) \\
\text { Range }\end{array}$ & $47.39(15.0 \%)$ & $64.16(12.5 \%)$ \\
Gender & $25-78$ & $27-87$ \\
Female & & $38(84.4 \%)$ \\
Male & $28(100 \%)$ & $7(15.6 \%)$ \\
Education & $0(0 \%)$ & \\
Some high school/high school & $12(26.7 \%)$ & $6(21.5 \%)$ \\
Some college/associate degree & $10(22.2 \%)$ & $13(46.4)$ \\
College/graduate education & $23(51.1 \%)$ & $9(32.2 \%)$ \\
Income & & \\
$\$ 45.000$ or more & $4(14.3 \%)$ & $23(51.1 \%)$ \\
Health & & \\
Poor & $1(3.6 \%)$ & $1(2.2 \%)$ \\
Fair & $6(21.4 \%)$ & $7(15.6 \%)$ \\
Good & $18(64.3 \%)$ & $21(46.7 \%)$ \\
Excellent & $3(10.7 \%)$ & $16(35.3 \%)$
\end{tabular}

First, to examine the differences between CA and AA CPD, we looked at scores on measures of burden, caregiver symptoms (depression, anxiety, somatic symptoms, and anger hostility), psychological well-being, positive cognitions, and personal and social resourcefulness.

The results of the study showed that CA caregivers reported greater burden than AA caregivers $(t=-3.68, p<.001)$. CAs also reported more anxiety $(t=-2.66, p<.01)$, depression $(t=-2.21, p$ $<.05)$, and hostility $(t=-2.30, p<.05)$ than AAs. AA caregivers reported higher mean scores than $C A$ caregivers on resourcefulness, and slightly higher mean scores on psychological well-being and positive cognitions; however, the mean differences between the two groups as indicated by $t$ test were not statistically significant (Table 3 ).

Second, to examine whether AAs and/or CAs would benefit from positive cognitions and resourcefulness training interventions, we examined the correlations between positive cognitions, personal and social resourcefulness, and the psychological well-being, perceived burden, and the symptoms subscale of the SQ for the total sample, for AA caregivers, and for CA caregivers (Table 3 ). Significant correlations between positive cognitions and psychological well-being were found

Perspectives in Psychiatric Care, Vol 51, No. 4 (October 2015): pg. 285-294. DOI. This article is (C Wiley and permission has been granted for this version to appear in e-Publications@Marquette. Wiley does not grant permission for this article to be further copied/distributed or hosted elsewhere without the express permission from. 
for the total sample $(r=.47, p<.001)$ and for CA caregivers $(r=.55$, $p<.001)$, but not for AA caregivers.

For the total sample, greater burden was significantly and negatively correlated with measures of positive cognitions $(r=-.34, p$ $<.001)$, social resourcefulness $(r=-.27, p<.01)$, and personal resourcefulness $(r=-.25, p<.01)$ (Table 3$)$. For CAs, significant correlations were found between burden and social resourcefulness ( $r$ $=-.31, p<.01)$

Furthermore, correlations in the expected directions were found between positive cognitions and scores on the symptoms subscale for the total sample $(r=-.31, p<.001)$ and for CAs $(r=-.41, p$ $<.001$ ), but not for AAs (Table 3 ). Although social resourcefulness was not associated with scores on the symptom subscale for the total sample and for AAs, it was associated with the symptom subscale for CA caregivers $(r=-.32, p<.01)$ (Table 2$)$. Finally, correlations between psychological well-being and personal resourcefulness were found for the total sample $(r=.46, p<.001)$ and for CAs $(r=.59, p$ $<.001)$. Furthermore, correlations between scores on symptom subscale and personal resourcefulness were found for the total sample $(r=-.29, p<.01)$ and for CAs $(r=-.45, p<.001)$, but not for AAs (Table 3).

Table 2. Comparison of African American and Caucasian Caregivers of Persons With Dementia on Caregiver Burden, Positive Cognitions, Resourcefulness, and Psychological Well-Being

\begin{tabular}{|c|c|c|c|c|}
\hline Variable & $\begin{array}{c}\text { Caucasian mean }(N \\
=45)\end{array}$ & $\begin{array}{l}\text { African American mean } \\
\qquad(N=28)\end{array}$ & $t$ score & $p$ valt \\
\hline 1. $* p<.05 ; * * p<$ & $.01 ; * * * p<.001$ & & & \\
\hline Perceived burden & 39.97 & 26.00 & $-3.68 * * *$ & .001 \\
\hline Positive cognition & 34.22 & 36.07 & 1.62 & .111 \\
\hline Resourcefulness & 98.76 & 103.14 & 1.01 & .318 \\
\hline Personal & 59.76 & 61.86 & .811 & .420 \\
\hline Social & 39.00 & 41.29 & 1.03 & .309 \\
\hline Symptoms subscale & 20.91 & 13.10 & $-2.21^{*}$ & .031 \\
\hline Anxiety & 6.44 & 3.67 & $-2.66 * *$ & .010 \\
\hline Somatic & 4.00 & 3.46 & -.59 & .558 \\
\hline Depression & 5.33 & 3.07 & $-2.21 *$ & .03 \\
\hline Hostility & 5.13 & 2.89 & $-2.30 *$ & .025 \\
\hline Psychological well-being & 17.53 & 18.36 & -.75 & .456 \\
\hline
\end{tabular}

Perspectives in Psychiatric Care, Vol 51, No. 4 (October 2015): pg. 285-294. DOI. This article is (C Wiley and permission has been granted for this version to appear in e-Publications@Marquette. Wiley does not grant permission for this article to be further copied/distributed or hosted elsewhere without the express permission from. 
Table 3. Correlations Among Positive Cognitions, Resourcefulness, and Psychological Well-Being in African American and Caucasian Caregivers

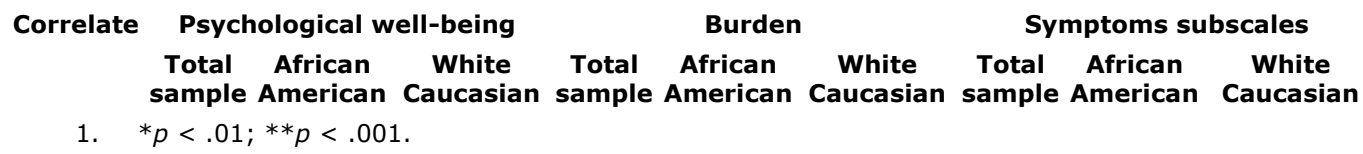

\section{Discussion}

Multiple factors affect the psychological well-being of CPD. These factors may be associated with the racial/ethnic group to which caregivers belong as well as their perceptions of burden, tendency toward positive thinking, and resourcefulness skills. In this study, AA caregivers differed from CA caregivers in their perceptions of the burden of caring for persons with dementia. CA caregivers reported significantly greater burden than AA caregivers, which is consistent with the findings of Haley et al. (1996), Hinrichsen and Ramirez (1992), Knight et al. (2000), and Lawton et al. (1992), who have reported that AA CPD experienced less burden than CA caregivers. Similarly, Macera et al. (1992) reported that AA caregivers reported less burden than CA caregivers. Additionally, previous research has shown that AA CPD consistently reported lower stress than CA caregivers, and AA caregivers viewed their stress as benign (Connell \& Gibson, 1997; Haley et al., 2004; Toth-Cohen, 2004).

In the present study, CA caregivers reported more anxiety, depression, and hostility than AA caregivers. This is consistent with the finding of Gonzalez (1997) that Anglo American CPD reported more depressive symptoms than AA caregivers. Similarly, Haley et al. (1995) found that $C A$ caregivers were more than twice as likely to be clinically depressed as to AA caregivers. Recent studies have also found that AA caregivers reported lower mean levels of depression than CA caregivers (Clay et al., 2008; Sleath et al., 2005; Sörensen \& Pinquart, 2005). Furthermore, a higher prevalence of anxiety and hostility has been reported for CA than for AA caregivers (Haley et al., 1995).

Perspectives in Psychiatric Care, Vol 51, No. 4 (October 2015): pg. 285-294. DOI. This article is (C) Wiley and permission has been granted for this version to appear in e-Publications@Marquette. Wiley does not grant permission for this article to be further copied/distributed or hosted elsewhere without the express permission from. 
In this study, AA caregivers had higher mean scores than CA caregivers on resourcefulness, positive cognitions, and psychological well-being although the differences between the two groups were not statistically significant, probably because of the small sample size especially for AAs. This, in fact, helps explain the findings of more burden, depression, anxiety, and hostility among CAs than AAs. That is, more positive cognitions and resourcefulness among AA caregivers might have acted as a buffer against anxiety, depression, and hostility. Future studies might consider replicating the present study with a larger sample to be able to detect these significant differences. The findings are similar to those of Gonzalez (1997), who found that AAs were more resourceful than Anglo Americans. However, it should be noted that Gonzalez used the self-control schedule (Rosenbaum, 1980) to measure resourcefulness while this study used the RS (Zauszniewski et al., 2006) to measure two aspects of resourcefulness: personal and social. Therefore, future research might consider replicating the present study using the RS that measures both forms of resourcefulness with a larger sample of AAs and CAs. The results of this study are also consistent with Knight et al. (2000), who found that AA caregivers used more positive reappraisal than CA caregivers, and with Haley et al. (1995), who found that AA caregivers were more resilient to the psychological stress of caregiving than CA caregivers.

It should be noted that more than half of the CA caregivers $(51.1 \%)$ reported having an income of $\$ 45,000$ or greater as compared to only $14.3 \%$ of the AA caregivers who reported having the same income ( $\$ 45,000$ or greater). The independent samples $t$ test between AAs and CAs regarding income is found to be statistically significant ( $t=3.07, p<.01$ ). The current study showed that despite the lower income for AAs as compared to CAs, AAs have less burden, less anxiety, less depression, and less hostility as compared to CAs. One possible explanation for the current results is that positive thinking and/or resourcefulness might act as a moderator or a mediator on the relationship between caregivers' contextual factors such as income and their burden and their psychological well-being. Therefore, future research might consider studying this contextual factor in relation to positive thinking and resourcefulness using a larger sample size.

Perspectives in Psychiatric Care, Vol 51, No. 4 (October 2015): pg. 285-294. DOI. This article is (C Wiley and permission has been granted for this version to appear in e-Publications@Marquette. Wiley does not grant permission for this article to be further copied/distributed or hosted elsewhere without the express permission from. 
This study indicated that social resourcefulness was associated with psychological well-being for the total sample, for AAs, and for CAs. Therefore, nurses should consider teaching social resourcefulness skills to CPD. Strategies for teaching social resourcefulness include helping CPD to recognize the need to seek external help and guidance when they are unable to function independently. Some specific strategies for teaching social resourcefulness include helping caregivers to rely on family and friends, exchanging ideas with other caregivers who were able to overcome the challenges of caregiving, and seeking professional help (e.g., from doctors or social workers) when appropriate. Finally, positive cognitions and personal resourcefulness were associated with greater psychological well-being for the total sample and for CAs. Therefore, CA caregivers may benefit from positive thinking and personal resourcefulness interventions that will have an impact on improving their psychological well-being. Examples of positive thinking and personal resourcefulness intervention strategies include reframing the situation in a positive way by helping caregivers to look at both the negative and the positive aspects of the situation and then train them on how they can use the positive aspects of the situation for their own advantage. Other strategies include helping caregivers to transform negative thoughts into positive thoughts, highlighting positive aspects of the situation, interrupting pessimistic thoughts by using relaxation techniques and distraction, recognizing the need to practice positive thinking, knowing how to break a problem into smaller parts to be manageable, initiating optimistic beliefs with each part of the problem, and generating positive feelings by controlling negative thoughts (Bekhet \& Zauszniewski, 2013).

The findings from this study clearly indicate a need to better understand how those with positive characteristics acquired them over the course of time prior to or during the caregiving process. Future qualitative research is recommended to understand the mechanism of developing positive cognitions and/or positive qualities among those caregivers who were able to overcome the challenges of caregiving and were able to find the positives in the caregiving experience.

Perspectives in Psychiatric Care, Vol 51, No. 4 (October 2015): pg. 285-294. DOI. This article is @ Wiley and permission has been granted for this version to appear in e-Publications@Marquette. Wiley does not grant permission for this article to be further copied/distributed or hosted elsewhere without the express permission from. 
NOT THE PUBLISHED VERSION; this is the author's final, peer-reviewed manuscript. The published version may be accessed by following the link in the citation at the bottom of the page.

\section{Limitations}

There are a number of limitations in the current study; some related to methodological issues and others related to sampling issues. First, the use of convenience sampling that came from a single location, including caregivers who are healthy and have greater positive cognitions, lower burden, and moderate levels of resourcefulness as indicated by the current findings, limited the generalizability of the study findings to all CPD (Bekhet, 2013). Second, the study was cross-sectional, making it difficult to assess resourcefulness over time. In fact, it has been postulated that resourcefulness is acquired throughout life (Rosenbaum, 1990). Therefore, given the nature of this cross-sectional study, it was not possible to take into account caregivers' previous resourcefulness or to follow them over time to see how they acquire resourcefulness as a result of caregiving and whether there is a change in their levels of resourcefulness over time. Future longitudinal study might consider measuring resourcefulness over time and investigating the relationship between time passed since caregiving and caregivers' levels of resourcefulness.

Another limitation is that the study used a secondary analysis; therefore, the researcher used the data that were available. If the study was a primary research, the distribution of the sample might be different in terms of recruiting more AA caregivers. Furthermore, more data could have been collected, such as the severity of the symptoms of persons with dementia that could have been a factor in the burden, anxiety, depression, and psychological well-being experienced by caregivers. We recommended that future research should assess the religion/spirituality of caregivers, perceived quality of current social supports, gender of the recipient of care, and the nature and the quality of the relationship between caregiver and recipient of care. Furthermore, we recommended that future demographic assessment should include the number of years providing care, number of individuals caregiver is giving care to, and personal family circumstances (number of children, work status, marital status, and personal health).

Perspectives in Psychiatric Care, Vol 51, No. 4 (October 2015): pg. 285-294. DOI. This article is (C Wiley and permission has been granted for this version to appear in e-Publications@Marquette. Wiley does not grant permission for this article to be further copied/distributed or hosted elsewhere without the express permission from. 
Of note, the study took place in the urban area of Wisconsin. Future research might replicate the study with rural caregivers as the characteristics of people and geographic location might shape the experience of CPD.

Despite these limitations, the findings add to our understanding of the relationships among the major components of resourcefulness theory: contextual factors, process regulators, resourcefulness skills, and QOL. According to Zauszniewski's resourcefulness theory, process regulators are intervening variables that mediate or moderate the effects of contextual factors on resourcefulness and QOL. Furthermore, personal and social resourcefulness may mediate/moderate the effects of process regulators on QOL. Therefore, caregivers might benefit from a resourcefulness training intervention to improve their QOL.

The findings of this study add to the body of nursing knowledge as this was the first study to examine the personal and social resourcefulness as related to burden, depression, anxiety, and psychological well-being in AA and CA CPD. Therefore, this study might serve as a starting point for further research related to personal and social resourcefulness among AA and CA CPD. The current study used a large effect size to detect statistical significance given the fact that this was the first study that compared AAs and CAs in relation to resourcefulness. However, the effect size obtained in this study for the resourcefulness variable was .24. Therefore, future research should consider using a small effect size to detect statistical significance. Replication of the study using a large sample size is recommended.

In fact, resourcefulness is a personal characteristic that is acquired throughout life, and because it is learned, it can be modified and strengthened over time. Given the nature of this cross-sectional study that measured resourcefulness at a single point in time, it is hard to determine caregivers' previous resourcefulness and whether resourcefulness was enhanced or deteriorated as a result of caregiving. Future studies might consider measuring the levels of resourcefulness among CPD and targeting those caregivers with low levels of resourcefulness who needed the intervention.

Perspectives in Psychiatric Care, Vol 51, No. 4 (October 2015): pg. 285-294. DOI. This article is (C Wiley and permission has been granted for this version to appear in e-Publications@Marquette. Wiley does not grant permission for this article to be further copied/distributed or hosted elsewhere without the express permission from 
NOT THE PUBLISHED VERSION; this is the author's final, peer-reviewed manuscript. The published version may be accessed by following the link in the citation at the bottom of the page.

\section{Clinical Relevance}

The results of this study have clinical relevance and implications for practice. The fact that resourcefulness is associated with psychological well-being among CPD can be used by geropsychiatric nurses to plan primary, secondary, and tertiary prevention strategies to help CPD to retain, attain, or maintain their optimal well-being. Primary prevention is directed toward promoting caregivers' psychological well-being by reducing the potential stressors that are anticipated as a result of the day-to-day burden associated with being a CPD. This can be achieved by reaching those caregivers who have a newly diagnosed relative with dementia and teaching them how they can use their personal and social resourcefulness to prevent the development of burden and the subsequent development of anxiety, depression, and poor psychological well-being. In fact, assessing an individual's attitude toward the caregiving, his or her strengths, and concerns is vital to facilitate the adjustment to the new role of being a caregiver. Secondary prevention can be implemented when stress symptoms develop. This level of intervention should encompass interventions to increase personal and social resourcefulness for those with existing stress as a result of the caregiving. Tertiary prevention would help the caregivers who have already developed depression, anxiety, and poor psychological well-being to use all existing internal and external resources to prevent further reactions or stress toward caregiving for the purpose of maintaining optimal client wellness.

In brief, personal resourcefulness intervention will include teaching caregivers to organize their daily activities, use positive selftalk, reframe the situation positively, change from usual reaction, and explore new ideas (Zauszniewski \& Bekhet, 2011). On the other hand, social resourcefulness intervention will include teaching caregivers how to rely on family and friends and how to seek their social support when needed (Zauszniewski \& Bekhet, 2011).

\section{Acknowledgments}

The author acknowledges the editorial assistance of Elizabeth M. Tornquist (University of North Carolina at Chapel Hill). Funding for the parent study was provided by the Regular Research Grant Award from Marquette University awarded to Dr. Abir Bekhet.

Perspectives in Psychiatric Care, Vol 51, No. 4 (October 2015): pg. 285-294. DOI. This article is (C Wiley and permission has been granted for this version to appear in e-Publications@Marquette. Wiley does not grant permission for this article to be further copied/distributed or hosted elsewhere without the express permission from. 
NOT THE PUBLISHED VERSION; this is the author's final, peer-reviewed manuscript. The published version may be accessed by following the link in the citation at the bottom of the page.

\section{References}

Alwin, J., Oberg, B., \& Krevers, B. (2010). Support/services among family caregivers of persons with dementia-perceived importance and services received. International Journal of Geriatric Psychiatry, 25(3), 240-248. doi: $10.1002 / \mathrm{gps} .2328$

Alzheimer's Association. (2012). 2012 Alzheimer's disease facts and figures. Retrieved from http://www.alz.org/documents_custom/2012_facts_figures_fact_sheet .pdf

Au, A., Li, S., Lee, K., Leung, P., Pan, P. C., Thompson, L., \& GallagherThompson, D. (2010). The Coping with Caregiving Group Program for Chinese caregivers of patients with Alzheimer's disease in Hong Kong. Patient Education and Counseling, 78(2), 256-260. doi: $10.1016 /$ j.pec.2009.06.005

Bekhet, A. (2013). Effects of positive cognitions and resourcefulness on caregiver burden among caregivers of persons with dementia. International Journal of Mental Health Nursing, 22(4), 340-346. doi:10.1111/j.1447-0349.2012.00877.x

Bekhet, A., \& Zauszniewski, J. (2013). Measuring use of positive thinking skills scale: Psychometric testing of a new scale. Western Journal of Nursing Research, 35(8), 1074-1093. doi: $10.1177 / 0193945913482191$

Bekhet, A., Zauszniewski, J. A., \& Wykle, M. (2008). Milieu change and relocation adjustment in elders. Western Journal of Nursing Research, $30(1), 113-129$.

Belgrave, L., Wykle, M., \& Choi, J. (1993). Health, double jeopardy, and culture: The use of institutionalization by African-Americans. Gerontologist, 33(3), 379-385.

Butcher, H. K., Holkup, P. A., \& Buckwalter, K. C. (2001). The experience of caring for a family member with Alzheimer's disease. Western Journal of Nursing Research, 23(1), 33-55.

Centers for Disease Control and Prevention (2011). Healthy aging: Helping people to live long and productive lives and enjoy a good quality of life. Retrieved from http://www.cdc.gov/chronicdisease/resources/publications/AAG/aging. htm

Chou, K. R., Chu, H., Tseng, C. L., \& Lu, R. B. (2003). The measurement of caregiver burden. Journal of Medical Sciences, 23(2), 73-82.

Clay, O. J., Roth, D. L., Wadley, V. G., \& Haley, W. E. (2008). Changes in social support and their impact on psychosocial outcome over a 5-year period for African American and White dementia caregivers.

Perspectives in Psychiatric Care, Vol 51, No. 4 (October 2015): pg. 285-294. DOI. This article is (C Wiley and permission has been granted for this version to appear in e-Publications@Marquette. Wiley does not grant permission for this article to be further copied/distributed or hosted elsewhere without the express permission from. 
NOT THE PUBLISHED VERSION; this is the author's final, peer-reviewed manuscript. The published version may be accessed by following the link in the citation at the bottom of the page.

International Journal of Geriatric Psychiatry, 23(8), 857-862. doi:10.1002/gps.1996

Cohen, J., \& Cohen, P. (1983). Applied multiple regression/correlation analysis for the behavioral sciences (2nd ed.). Hillsdale, $\mathrm{NJ}$ : Lawrence Erlbaum Associates.

Connell, C. M., \& Gibson, G. D. (1997). Racial, ethnic, and cultural difference in dementia caregiving: Review and analysis. Gerontologist, 37(3), 355-364.

Cooper, C., Katona, C., Orrell, M., \& Livingston, G. (2006). Coping strategies and anxiety in caregivers of people with Alzheimer's disease: The LASER-AD study. Journal of Affective Disorder, 90(1), 15-20.

Cooper, C., Balamurali, T., \& Livingston, G. (2007). A systematic review of the prevalence and associates of anxiety in caregivers of people with dementia. International Psychogeriatrics, 19(2), 175-195.

Cooper, C., Balamurali, T., Selwood, A., \& Livingston, G. (2007). A systematic review of the treatment of anxiety in caregivers of people with dementia. International Journal of Geriatric Psychiatry, 22(3), 181188.

Cooper, C., Katona, C., Orrell, M., \& Livingston, G. (2008). Coping strategies, anxiety, and depression in caregivers of people with Alzheimer's disease. International Journal of Geriatric Psychiatry, 23(9), 929-936. doi:10.1002/gps.2007

Depp, C., Sorocco, K., Kasl-Godley, J., Thompson, L., Rabinowitz, Y., \& Gallagher-Thompson, D. (2005). Caregiver self-efficacy, ethnicity, and kinship differences in dementia caregivers. American Journal of Geriatric Psychiatry, 13(9), 787-794.

Di Mattei, V. E., Prunas, A., Novella, L., Marcone, A., Cappa, S. F., \& Sarno, L. (2008). The burden of distress in caregivers of elderly demented patients and its relationship with coping strategies. Neurological Sciences, 29(6), 383-389. doi:10.1007/s10072-008-1047-6

Duggleby, W., Williams, A., Wright, K., \& Bollinger, S. (2009). Renewing everyday hope: The hope experience of family caregivers of persons with dementia. Issues in Mental Health Nursing, 30(8), 514-521. doi: $10.1080 / 01612840802641727$

Etters, L., Goodall, D., \& Harrison, B. E. (2008). Caregiver burden among dementia patient caregivers: A review of the literature. Journal of the American Academy of Nurse Practitioners, 20(8), 423-428. doi:10.1111/j.1745-7599.2008.00342.x

Fisher, G. G., Franks, M. M., Plassman, B. L., Brown, S. L., Potter, G. G., Llewellyn, D., ... Langa, K. M. (2011). Caring for individuals with dementia and cognitive impairment: Findings from the aging, demographics, and memory study. Journal of the American Geriatrics Society, 59(3), 488-494. doi:10.1111/j.1532-5415.2010.03304.x

Perspectives in Psychiatric Care, Vol 51, No. 4 (October 2015): pg. 285-294. DOI. This article is (C Wiley and permission has been granted for this version to appear in e-Publications@Marquette. Wiley does not grant permission for this article to be further copied/distributed or hosted elsewhere without the express permission from. 
Flynn Longmire, C. V., \& Knight, B. G. (2010). Confirmatory factor analysis of the Center for Epidemiologic Studies-Depression Scale in black and white dementia caregivers. Aging \& Mental Health, 14(8), 962-970. doi: $10.1080 / 13607863.2010 .501060$

Gonzalez, E. W. (1997). Resourcefulness, appraisals, and coping efforts of family caregivers. Issues in Mental Health Nursing, 18(3), 209-227.

Haley, W. E., West, C. A., Wadley, V. G., Ford, G. R., White, F. A., Barrett, J. J., ... Roth, D. L. (1995). Psychological, social, and health impact of caregiving: A comparison of black and white dementia family caregivers and noncaregivers. Psychology and Aging, 10(4), 540-552.

Haley, W. E., Roth, D., Coleton, M., Ford, G., West, C., Collins, R., \& Isobe, T. (1996). Appraisal, coping and social support as mediators of well-being in Black and White family caregivers of patients with Alzheimer's disease. Journal of Consulting and Clinical Psychology, 64(1), 121129.

Haley, W. E., Gitlin, L. N., Wisniewski, S. R., Mahoney, D. F., Coon, D. W., Winter, L., ... Ory, M. (2004). Well-being, appraisal, and coping in African-American and Caucasian American dementia caregivers: Findings from the REACH study. Aging \& Mental Health, 8(4), 316329.

Hinrichsen, G., \& Ramirez, M. (1992). Black and White dementia caregivers: A comparison of their adaptation, adjustment, and service utilization. Gerontologist, 32(3), 375-381.

Huang, H. L., Chang, M. Y., Tang, J. S., Chiu, Y., \& Weng, L. C. (2008). Determinants of the discrepancy in patient and caregiver rated quality of life for persons with dementia. Journal of Clinical Nursing, 18(22), 3107-3117. doi:10.1111/j.1365-2702.2008.02537.x

Kellner, R. (1987). A symptom questionnaire. Journal of Clinical Psychiatry, 48(7), 268-274.

Kim, H., Chang, M., Rose, K., \& Kim, S. (2012). Predictors of caregiver burden in caregivers of individuals with dementia. Journal of Advanced Nursing, 68(4), 846-855. doi:10.1111/j.1365-2648.2011.05787.x

Knight, B., Silverstein, M., McCallum, T., \& Fox, L. (2000). A sociocultural stress and coping model for mental health outcomes among African American caregivers in Southern California. Journal of Gerontology: Psychological Sciences, Series B, 55(3), 142-150.

Lawton, M., Rajagopal, D., Brody, E., \& Kleban, M. (1992). The dynamics of caregiving for a demented elder among Black and White families. Journal of Gerontology: Social Sciences, 47(4), S156-S164.

Macera, C. A., Eaker, E. D., Goslar, P. W., Deandrade, S. J., Williamson, J. S., Cornman, C., \& Jannarone, R. J. (1992). Ethnic differences in the burden of caregiving. American Journal of Alzheimer's Disease and Related Disorders \& Research, 7(5), 4-7.

Perspectives in Psychiatric Care, Vol 51, No. 4 (October 2015): pg. 285-294. DOI. This article is (C Wiley and permission has been granted for this version to appear in e-Publications@Marquette. Wiley does not grant permission for this article to be further copied/distributed or hosted elsewhere without the express permission from. 
NOT THE PUBLISHED VERSION; this is the author's final, peer-reviewed manuscript. The published version may be

accessed by following the link in the citation at the bottom of the page.

Munro, B. H. (1997). Statistical methods for health care research (3rd ed.). Philadelphia: Lippincott.

Oken, B. S., Fonareva, I., \& Wahbeh, H. (2011). Stress-related cognitive dysfunction in dementia caregivers. Journal of Geriatric Psychiatry and Neurology, 24(4), 191-198. doi:10.1177/0891988711422524

Pinquart, M., \& Sörensen, S. (2004). Associations of caregiver stressors and uplifts with subjective well-being and depressive mood: A metaanalytic comparison. Aging \& Mental Health, 8(5), 438-449.

Plassman, B. L., Langa, K. M., Fisher, G. G., Heeringa, S. G., Weir, D. R., Ofstedal, M. B., \& Wallace, R. B. (2007). Prevalence of dementia in the United States: The aging, demographics, and memory study. Neuroepidemiology, 29(1-2), 125-132.

Romero-Moreno, R., Losada, A., Mausbach, B. T., Márquez-González, M., Patterson, T. L., \& López, J. (2011). Analysis of the moderating effect of self-efficacy domains in different points of the dementia caregiving process. Aging \& Mental Health, 15(2), 221-231. doi: $10.1080 / 13607863.2010 .505231$

Rosenbaum, M. (1980). A schedule for assessing self-control behaviors: Preliminary findings. Behavior Therapy, 11(1), 109-121.

Rosenbaum, M. (1990). Learned resourcefulness on coping skills, self-control, and adaptive behavior. New York: Springer.

Sörensen, S., \& Pinquart, M. (2005). Racial and ethnic differences in the relationship of caregiving stressors, resources, and sociodemographic variables to caregiver depression and perceived physical health. Aging and Mental Health, 9(5), 482-495.

Schoenmakers, B., Bntinx, F., \& Delepeleire, J. (2010). Factors determining the impact of ca giving on caregivers of elderly patients with dementia. A systematic literature review. Maturitas, 66(2), 191-200. doi: $10.1016 /$ j.maturitas.2010.02.009

Schultz, R., \& Martire, L. M. (2004). Family caregiving of persons with dementia. American Journal of Geriatric Psychiatry, 12(3), 240-249.

Sleath, B., Thorpe, J., Landerman, L. R., Doyle, M., \& Clipp, E. (2005). African-American and White caregivers of older adults with dementia: Differences in depressive symptomatology and psychotropic drug use. Journal of the American Geriatrics Society, 53(3), 397-404.

Stone, P. W. (2001). What's the big deal about missing data? Applied Nursing Research, 14(4), 225-226.

Thompson, E. H., Jr., Futterman, A. M., Gallagher-Thompson, D., Rose, A. M., \& Lovett, S. B. (1993). Social support and caregiving burden in family caregivers of frail elders. Journal of Gerontology, 48, 245-254.

Toth-Cohen, S. (2004). Factors influencing appraisal of upset in black caregivers of persons with Alzheimer disease and related dementias. Alzheimer Disease and Associated Disorders, 18(4), 247-255.

Perspectives in Psychiatric Care, Vol 51, No. 4 (October 2015): pg. 285-294. DOI. This article is (C Wiley and permission has been granted for this version to appear in e-Publications@Marquette. Wiley does not grant permission for this article to be further copied/distributed or hosted elsewhere without the express permission from. 
NOT THE PUBLISHED VERSION; this is the author's final, peer-reviewed manuscript. The published version may be

accessed by following the link in the citation at the bottom of the page.

Tremont, G. (2011). Family caregiving in dementia. Medicine \& Health, 94(2), 36-38.

Van Vliet, D., de Vugt, M. E., Bakker, C., Koopmans, R. T., \& Verhey, F. R. (2010). Impact of early onset dementia on caregivers. International Journal of Geriatric Psychiatry, 25(11), 1091-1100. doi:10.1002/gps.2439

Willis, L., Thomas, P., Garry, P. J., \& Goodwin, J. S. (1987). A prospective study of response to stressful life events in initially healthy elders. Journal of Gerontology, 42(6), 627-630.

Young, R. F., \& Kahana, E. (1995). The context of caregiving and wellbeing outcomes among African and Caucasian Americans. Gerontologist, $35(2), 225-232$.

Zauszniewski, J. A. (1994). Health seeking resources and adaptive functioning in depressed and non-depressed adults. Archives of Psychiatric Nursing, 8(3), 159-168.

Zauszniewski, J. A. (1995). Development and testing of a measure of depressive cognition in older adults. Journal of Nursing Measurement, $3(1), 31-41$.

Zauszniewski, J. A. (1997). The Depressive Cognition Scale: Further psychometric evaluation. Journal of Nursing Measurement, 5(2), 191200.

Zauszniewski, J. A. (2006). Resourcefulness: A new mid-range theory. In J. J. Fitzpatrick \& M. Wallace (Eds.), Encyclopedia of nursing research (pp. 256-258). New York: Springer.

Zauszniewski, J. A., \& Bekhet, A. (2011). Measuring use of resourcefulness skills: Psychometric testing of a new scale. International Scholarly Research Network Journal. doi:10.5402/2011/787363

Zauszniewski, J. A., Chung, C. W., \& Krafcik, K. (2001). Social cognitive factors predicting the health of elders. Western Journal of Nursing Research, 23(5), 490-503.

Zauszniewski, J. A., Chung, C. W., Krafcik, K., \& Sousa, V. D. (2001). Psychometric testing of the Depressive Cognition Scale in women with type 2 diabetes. Journal of Nursing Measurement, 9(1), 61-72.

Zauszniewski, J. A., McDonald, P. E., Krafcik, K., \& Chung, C. W. (2002). Acceptance, cognitions, and resourcefulness in women with diabetes. Western Journal of Nursing, 24(7), 728-743.

Zauszniewski, J. A., Lai, C. Y., \& Tithiphontumrong, S. (2006). Development and testing of the resourcefulness scale for older adults. Journal of Nursing Measurement, 14(1), 57-68.

Zauszniewski, J. A., Bekhet, A., Lai, C., McDonald, P. E., \& Musil, C. M. (2007). Effects of teaching resourcefulness and acceptance on affect, behavior, and cognition of chronically ill elders. Issues in Mental Health Nursing, 28(6), 575-592.

Perspectives in Psychiatric Care, Vol 51, No. 4 (October 2015): pg. 285-294. DOI. This article is (C Wiley and permission has been granted for this version to appear in e-Publications@Marquette. Wiley does not grant permission for this article to be further copied/distributed or hosted elsewhere without the express permission from. 
NOT THE PUBLISHED VERSION; this is the author's final, peer-reviewed manuscript. The published version may be accessed by following the link in the citation at the bottom of the page.

Perspectives in Psychiatric Care, Vol 51, No. 4 (October 2015): pg. 285-294. DOI. This article is (C Wiley and permission has been granted for this version to appear in e-Publications@Marquette. Wiley does not grant permission for this article to be further copied/distributed or hosted elsewhere without the express permission from. 